\title{
The Magic of Columba
}

\author{
by O. G. S. CrawFord
}

$\mathrm{C}$ OLUMBA was the virtual founder of the Church of Scotland, and the life by his successor Adamnan has almost the authority of a contemporary document. ${ }^{1}$ The author naturally extols the prowess of his hero ; and it is by no means easy to discern the real man through the hagiographical haze that now surrounds him. Opinions have differed widely, but all are agreed that he was quick-tempered. 'Primitive Irish ecclesiastics, and especially the superior class, commonly known as Saints, were very impatient of contradiction, and very resentful of injury. Excommunication, fasting against, and cursing, ${ }^{2}$ were in frequent employment, and inanimate as well as animate objects are represented as the subject of their maledictions. St. Columba, who seems to have inherited the high bearing of his race, was not disposed to receive injuries, or even affronts, in silence. Adamnan relates (Lib. II, cap. 22) how he pursued a plunderer with curses, following the retiring boat into the sea until the water reached to his knees. We have an account (Lib. II, cap. 20) also of his cursing a miser who neglected to extend hospitality to him. On another occasion (Lib. II, cap. 24), in Hinba, he excommunicated some plunderers of the church ; and one of them afterwards perished in combat, being transfixed with a spear which was discharged in St. Columba's name. Possibly some current stories of the saint's imperious and vindictive temper may have suggested to Venerable Bede (Hist. Eccl., Lib. III,

${ }^{1}$ Columba was born in $52 \mathrm{I}$ and died in 597 ; Adamnan probably wrote his Life between the years 692 and 697 . The picture which he gives may therefore be taken to represent the monastery of Iona as it was in the 7 th century.

${ }^{2}$ Cursing and fasting against. For the first, see L. Gougaud, Christianity in Celtic Lands, 1932, 53, note 4, quoting C. Plummer, V.S.H., I, pp. ClXxiII-IV ; P. Power, Early Christian Ireland (Dublin, 1925) 100-I ; Giraldus, Itin. Kambriae (ed. J. F. Dimock) I, 2 : II, 7 (pp. 27, 130); see also Baring Gould \& Fisher, Lives of the Saints, $\mathrm{I}, 1907, \mathrm{I} 3 \mathrm{ff}$. For fasting against, see L. Gougaud, op. cit. 97-8, and references given there ; and Baring Gould \& Fisher, op. cit. I fff. 


\section{PLATE I}

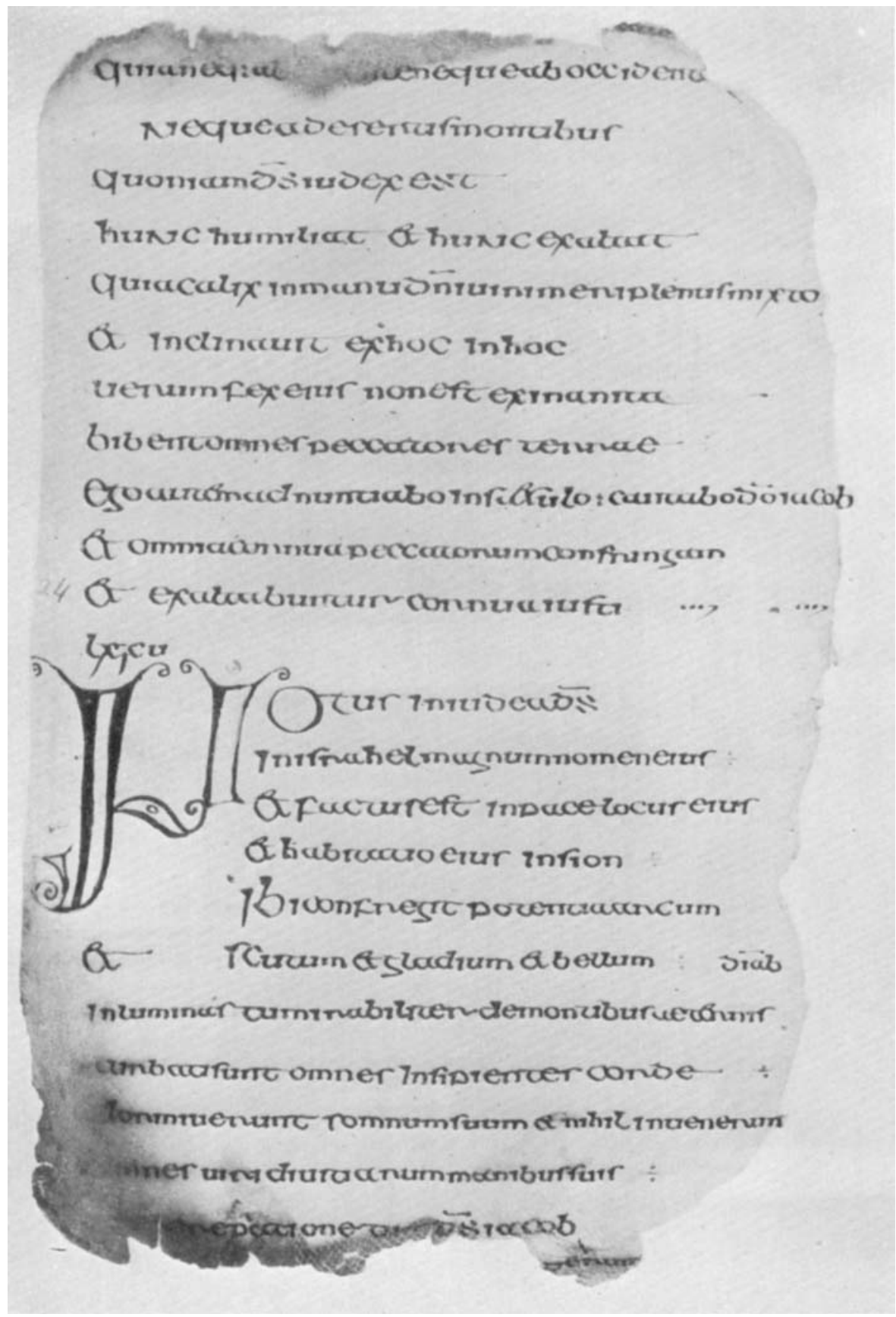

A PAGE OF THE CATHACH, POSSIBLY IN THE HANDWIRITING OF ST, COLUMBA Ph. Royal Irish Academy 
PLATE II

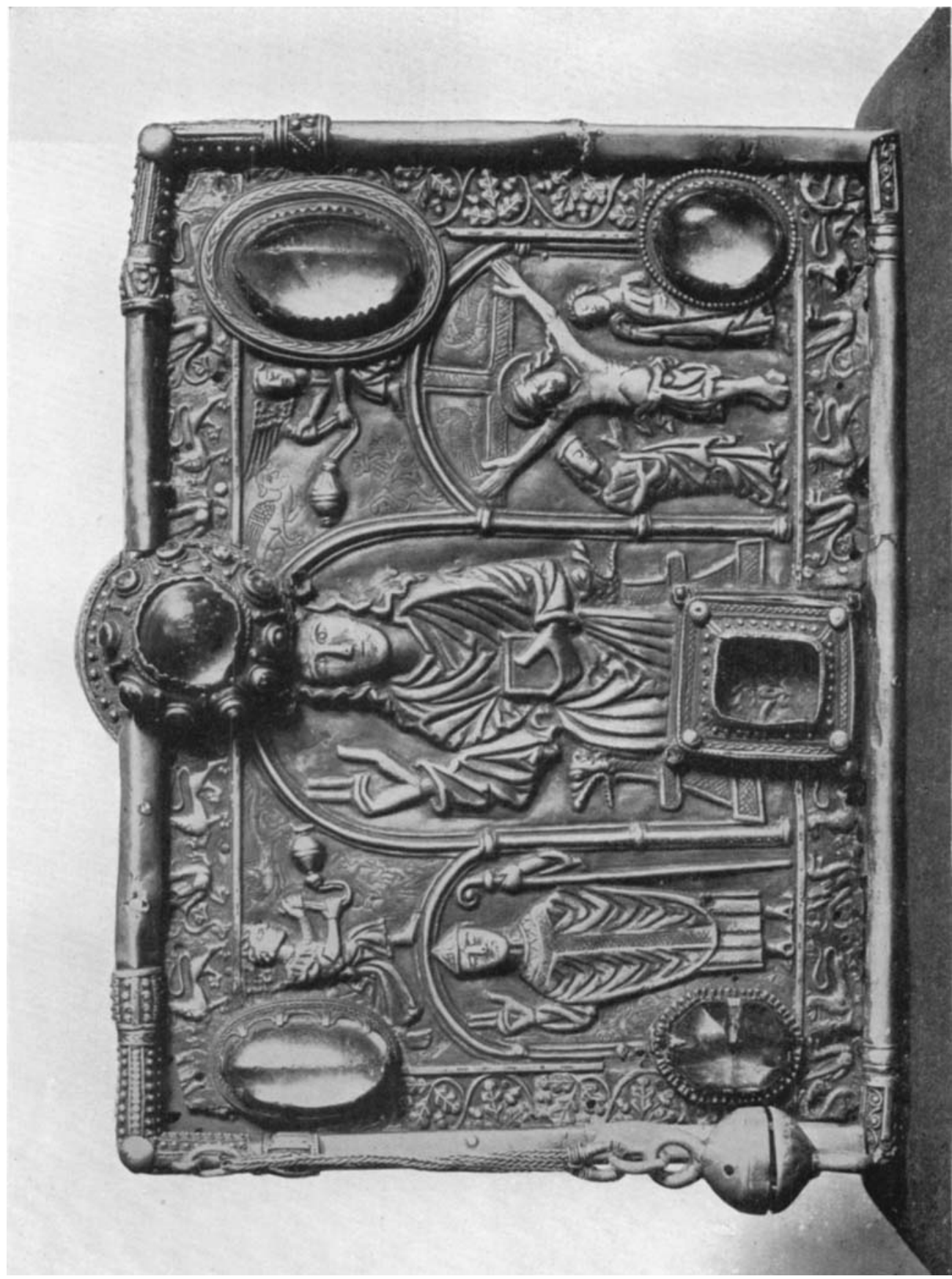

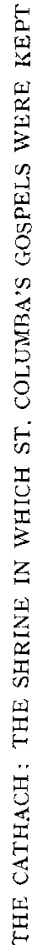




\section{THE MAGIC OF COLUMBA}

cap. 4) the qualified approbation 'qualiscumque fuerit ipse, nos hoc de illo certum tenemus, quia reliquit successores magna continentia ac divino amore regularique institutione insignes ' ${ }^{3}$ In view of these facts $\mathrm{Dr}$ Simpson ${ }^{4}$ is surely entitled to speak of "the combination of ferocity and craft that formed a marked feature of his highly complex and tinted character'. Dr Duke, who protests strongly against this passage in particular, himself speaks ${ }^{5}$ of Columba's 'imperious and passionate nature'; and evidence of his craft abounds throughout the Life, especially in book II. We shall come across instances later.

The clue to Columba's life, and to much that is puzzling in early Celtic Christianity, is to be found in magic. "The "sanctifying grace" of the legendary saint neither arose from habitual virtue nor resulted primarily in holiness ; it was the Christianised counterpart of the magic potency of the druid' ${ }^{6}$ "With the acceptance of Christianity the saints simply occupied the shells left vacant by the druids who had disappeared ' 7 This stands out plainly in certain passages where Columba and the heathen magi confront each other. In reading Adamnan's Life we receive the impression of two rival groups of sorcerers competing for recognition before the King of the Picts and his people. Thus on four separate occasions when Columba 'threw a miracle', the magi are mentioned as defeated rivals. ${ }^{8} \mathrm{He}$ turns a bad spring into a good one, thereby disappointing the magi who hoped the water would infect him with disease. He holds up the attack of a monster in the river Ness, so that the heathen (gentiles barbari) are forced, by the greatness of the miracle, performed before their eyes, to magnify the god of the Christians. He brings back to life the dead son of a recent convert, thus confounding the taunts of the magi. He sails up wind on the stated day for his departure, and so publicly confutes Broichan, the chief magus of King Brude.

${ }^{3}$ William Reeves (Editor), Life of St. Columba, written by Adamnan (1857), IxxvII.

The Historical St. Columba, 1927, p. 2.

${ }^{5}$ Dr Duke's phraseology suggests that Dr Simpson has committed a sin or even (much worse) a breach of good manners and taste by adopting an unfavourable view of Columba's character ! (As I have said already [AN'TiQUITY VII, 453] I regard Dr Simpson's main thesis as by no means proven; but that is not the point).

${ }^{6}$ J. F. Kenney, Sources for the Early History of Ireland, 1, 303; quoted by Duke, 56 , note 1 .

${ }^{7}$ Lives of the British Saints, by the Rev. S. Baring Gould and Canon T. Fisher, I, $1907,10$.

${ }^{8}$ Reeves, I19, I40-2, 145-6, 148-50. 


\section{AN'TIQUITY}

'The truth of the matter seems to have been ', says Dr Duke, ' that St. Columba himself had not advanced very far out of the darkness which surrounded him, and that his own mind was shadowed by a very real belief in many of the superstitions of his age '. Such an admission makes it unnecessary to do more than cite a few incidents by way of illustration.

Note, for example, Adamnan's use of the words benedictio, benedicare. Columba found a white stone in the river Ness, blessed it and used it to cure his old rival Broichan, the witch-doctor of King Brude, from a severe illness ; having first secured from him by blackmail a promise which, before, Broichan had refused to give. The stone (perhaps pumice) had the quality of floating in water-nec potuit sancti benedictio submergi-nor could the saint's charm be sunk. On four other occasions water imbued with Columba's benedictio cures illness $^{10}$; on another his benedictio is preferred to the gift of a sword. ${ }^{11}$ That it was regarded as an asset of practical value is proved by the story of the blessed stake (veru) which successively impaled stags, and a dog, goat, salmon and crow. ${ }^{12}$ We are told of bread, rock-salt, a chariot and a barn being blessed by Columba; and the last act of his life was to bless the monks, with raised hand. ${ }^{13}$

The sign of the cross (signum salutare) had similar magic powers; hence it was customary, before milking, to cross the pail, and before tools were used to cross them. It was considered effectual to banish demons, to restrain a river-monster, to prostrate a wild beast, and to unlock a door ${ }^{14}$ Other instances of charms are cited by Reeves, ${ }^{15}$ who adds that a belief in them was not peculiar to Columba or his nation, but 'was professed in equal variety and firmness by the venerable father of Saxon history' $1{ }^{16}$

Columba's method of conversion was apparently to tackle the king first, then his magi and last of all his subjects. This is a legitimate inference both from Adamnan's narrative and from the recorded acts of other missionaries, such as Augustine, Paulinus, Boniface. ${ }^{17}$ It

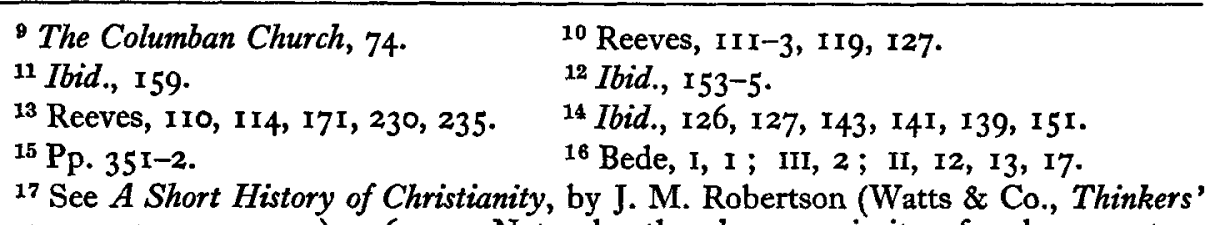
Library, no. $24 ; 1931 ;$ Is), 126-31. Note also the close proximity of early monastery and royal seat at Lindisfarne (Bamborough), Glasgow (Dumbarton), and perhaps also at St. Davids, Derry and Abernethy. 


\section{THE MAGIC OF COLUMBA}

was necessary to prove to the king that Christian magic was stronger than the magic of the local magi. Some of the means used have already been described. One argument which undoubtedly appealed strongly to these kinglets was a guarantee of success in battle. Magical means of securing victory were fasting, singing, and the use of relics. All three methods are well authenticated in early British and Irish history. At the battle of Chester (6I6), between Aethelfrith of Northumbria and the Britons, a band of Christian monks after a three days' fast chanted songs from a post of imagined security. That their action was regarded by the enemy as dangerous may be concluded from the fact that they were all deliberately killed. Bede ${ }^{18}$ records Aethelfrith as saying that 'if they cry to their God against us, they fight against us as surely as do those who bear weapons'.

We have no good evidence of Columba's direct magical intervention in any individual battle. ${ }^{19}$ Later tradition attributed to him the writing of the Psalter known as the Cathach, ${ }^{20}$ which undoubtedly was carried into battle. ${ }^{21}$ (PLATES I, II). Similar magical powers are attributed by modern primitive peoples to the written word. Extracts from the Koran in the form of amulets are still used as charms to protect life, and in every modern war bibles carried by soldiers have been claimed to have saved lives. There can however be little doubt that his influence with the kinglets of the time rested on such a belief; indeed Adamnan says, ${ }^{22}$ that Columba by the power of his prayers (virtute orationum) secured victory for one side and defeat for the other. This power, he says, continued after death ; he tells how Columba's battlemagic secured for Oswald of Northumbria the victory of Hefenfeltha story he got from Failbhe who had it from Oswald himself. ${ }^{23}$

${ }^{18}$ Lib. Ir, cap. 2. ${ }^{19}$ Compare, however, Adamnan, I, caps. 7, 8, 12.

20 Still preserved in the National Museum, Dublin. The Cathach was the subject of a very elaborate paper by Messrs. H. C. Lawlor and E. C. R. Armstrong (Proc. $R$. Irish Academy, vol. xxxIII, sect. c, I916-17, 24I-443). The palaeographical part, which forms the most important section of this paper, leaves very little doubt about the genuineness of the tradition (which is at least as old as the IIth century) that the manuscript is as old as it has always been claimed to be. On the other hand it is impossible to state that it was either used or written by St. Columba himself. It may be said that the manuscript almost certainly belongs to St. Columba's time.

I wish to thank the authorities concerned, and Dr Mahr himself, for facilities in obtaining these two illustrations, and for permission to publish them.

${ }^{21}$ Reeves, 250, quoting O'Donnel and the Four Masters, s.a.555. If carried three times right-wise round an army by a pure cleric, a safe and victorious return was ensured.

22 Lib. I, cap. I (Reeves, 13). ${ }^{23}$ Reeves, 16. 


\section{ANTIQUITY}

Thus fortified, after the battle Oswald sent to Iona for missionarieshence Aidan and Lindisfarne and Northumbrian Christianity. The Hallelujah victory is another instance. ${ }^{24}$

The practice of battle-magic was common throughout early times in Great Britain and Ireland, and deserves to be studied objectively. Here I can do no more than throw out a few suggestions. What evidence is there of pre-Christian battle-magic? It is unlikely that the practice was invented by the early Christian missionaries. What is its subsequent history? Does early Welsh and Irish literature throw any light upon the subject of origins? The later developments of this essentially magical practice may be studied today in any European country. Such a ceremony as that of blessing the colours is pure magic, and the colours themselves are directly descended from the earlier Christian charms. The association of the Christian church with the armed forces is itself to be traced back to magical origins. In the process of time, however, some specialization of function has taken place; and some of the offices performed, for instance, by the monks of Bangor have now devolved upon the regimental band.25

${ }^{24}$ Bede, I, cap. 2 I.

${ }^{25}$ The following additional instances of battle magic may be cited :-The name of the tribal god of the Jews was Yahweh Sabaoth=Yahweh of the Armies or Lord God of Hosts (E. E. Kellet: A short history of religions, 1933, p. 46). St. Teilo prayed for victory in battle (Lib. Land., ed. G. Evans, 1893, p. 123). A priest blessing a war-standard is figured in Proc. Soc. Ant. Scot. ser. 2, Xxiv, 1912, plate opp. p. 168 . Here a warrior in armour holds forth a lance for the archbishop to bless. It comes from a psalter of St. Jerome written for Ernulph, archbishop of Milan, A.D. 998-ror8.

I am indebted to Professor William Rees for drawing my attention to the following passages in the Black Book of St. Davids (A.D. I326) :-

p. 36. The burgesses of the town of St. Davids in time of war were bound to follow the Lord Bishop with the shrine of the Blessed David and with the relics on either side (et cum reliquiis ex utraque parte).

p. 8I. (A similar service was due from the copyholders of Trevine near St. Davids, within the lordship).

p. 89. The free-holders of Maboris 'ought to follow the Lord and his host in time of war, and ought to follow the relics of the blessed David to Carntrevy' (i.e. to the boundary of the lordship).

p. 95. Knights also of the lordship were liable for the same service.

p. 123. Tenants who hold by deed at Wolf's Castle in the bishop's land of St. Davids ' they ought to follow the shrine with the relics of the Blessed David in war-time and out of war-time as far as Carntrevy '.

p. I 53. The burgesses of the town of Llawhaden (in the bishop's lordship of Llawhaden): 'and if the bishop in time of war shall make a progress through his bishopric with the relics of the Blessed David, they ought to follow him to the town of Carmarthen'. 


\section{THE MAGIC OF COLUMBA}

In early Christian times, however, priests and monks took part in battles like everyone else. Columba himself is said to have taken part in three. ${ }^{26}$ One of them was fought against Comgall (517-602), the founder and first abbot of Bangor, ' about a church', evidently some dispute about ecclesiastical jurisdiction. It took place at Coleraine in Ulster at some date after 563 , which was the year of Columba's migration to Iona. Even purely ecclesiastical battles were not uncommon. In the year $76_{3}$ a battle was fought at Argamoyn between the fraternities of Clonmacnois and Durrow, one of Columba's own foundations; the latter was defeated with the loss of 200 men. In 8r6 a battle was fought between the fraternities of Tigh Munna and Ferns, in which 400 were slain. The annalist adds the interesting fact that 'the fraternity of Colum-cille (Columba) went to Tara to curse (King) Aedh '.27 The fact that in 804 ' the monastic communities of Ireland were formally exempted from military service ${ }^{\prime 28}$ shows that the holy warriors of 816 must have been volunteers or enthusiasts. As Reeves pointed out however the custom was not peculiar to Ireland. ${ }^{29}$

An unbiassed reader of Adamnan's Life will probably conclude that the religion there displayed was a form of magic differing in no essential feature from that of any other primitive people, ancient or modern. 'Conversion' was a mere transference of allegiance from one magic power (or group of powers) to another, believed to be more powerful. The religion of Columba had as little, or as much, in common with the religion of any Scottish minister of today as the barbarous life he led has with theirs. Both are negative reflections of the society of their day-no more.

How negative and unproductive that religion was we may see by comparing, for instance, the Scotland of Columba's time with the Scotland of the 16 th or 17 th centuries; and both with modern Scotland. A thousand years of Christianity did less to civilize the country than, for instance, a few decades of good communications by land and sea. But of course there were many other factors involved.

Columba's character was undoubtedly strong and influential ; he

${ }^{26}$ Liber Hymnorum, quoted by Reeves, p. 252 (IIth century Ms., but ' the prefaces [where the battles are referred to] have historical value only as evidence of traditions. There is no proof of the authenticity of the hymns attributed to Columba'; A. O. Anderson, Early Sources of Scottish History, I, I922, LXXII, LXXIII).

${ }^{27}$ Reeves, 255 .

${ }^{28}$ Ibid.

${ }^{29}$ See Gregory of Tours, Hist. Franc. Iv, 4I ; v, I7. 


\section{ANTIQUITY}

may in addition have had personal charm. But his historical importance and that of his fellow-missionaries, though admittedly great, have been grossly exaggerated for purposes of religious controversy.

\section{MrRaCles of Columba, with page-references to Reeves's Adamnan (edition of 1857 )}

Water into wine, 103-5.

Sour apples into sweet, 105.

Corn planted after midsummer and reaped early in August, ro6-7. Broken bone mended by holy water (benedictio), I I I-3.

Illness cured by a charm (benedictio), II3.

Rock-salt ( $a$ sancto benedicta) and beams unburnt, $\mathrm{rr}_{4}$.

Book written by him unharmed by 20 days in river, $114-6$.

Another similar miracle, Ir6-8.

Water from rock, I 8 .

Converts a bad spring into a good one, confuting the magi, II9.

Allays a storm when at sea, II9-20.

Another similar, through agency of Cainnich, I20-2.

Sends Cainnich his baculus miraculously across sea, r23.

Provides favourable winds on same day for two saints going in opposite directions, $124-5$.

Asked to bless milk; accident, caused by demon lurking in empty pail, because boy did not make sign of cross; Columba blesses half empty pail, miraculously filled, 126 .

Milk from an ox proved to be blood, the ox cured, $126-7$.

Cures nose-bleed, r27-8.

Causes a large fish to be caught (two miracles, more or less similar), 128-30.

Blesses a poor man's heifers and foretells great increase, I30-I.

Another similar miracle, I3I.

Blesses a barn, 230.

Curses a brigand and foretells his shipwreck (successfully), $13^{2-4.30}$

Foretells death of a wicked man before eating autumn pork, $134-5$.

Tells at a distance of the death of one who tried to kill him, 135-7.

Foretells the immediate death of a murderer, $137-8$.

Holds up the rush of a wild boar in a wood in Skye, $138-40$.

${ }^{30}$ There is a strong suggestion that in this and the three ensuing miracles the wish was magical father of the thought, and had a causative influence on the result. 


\section{THE MAGIC OF COLUMBA}

Does the same of a beast in the river Ness, and thereby proves superior efficacy of the god of the Christians before gentiles barbari, I40-2. Foretells future immunity of men and pecora from snake-bite, 142.

Blesses an iron tool (by request) so that it cannot harm men or pecora, I43.

Foretells that Diormit, when ill, shall survive him, I44.

Foretells that Finten, when ill, shall survive him, I44.

Brings back to life the dead son of a recent convert, to the confusion of the magi, $145-6$.

Threatens Broichan (magus of Brude) with death, 146 .

Finds a white stone in the Ness and endows it with magic healing properties, $146-7$.

Cures Broichan with it (note use of term benedictio for the stone itself), I48.

Sails up wind and publicly confutes Broichan, 148-50.

Opens the portus munitionis of Brude with the sign of the cross, I50-2. Opens a door in a monastery in Ireland, ${ }_{52-3}$.

Blesses a stake for a poor man, which impales stags, a dog, a goat, a salmon and a crow, I 53-5.

Foretells and possibly assists miraculously the return of a leather milkpail by the sea, $155^{-6}$.

Foretells events and, through Libranus, controls wind for sailors, $156-63$

Makes up a matrimonial quarrel, I64-6.

Provides by prayer a favourable wind for Cormac's return, I70-I.

After death brings rain after a drought, r 74-6.

After death affects the course of the wind (three separate occasions), I76-82.

Immunity of Picts and Scots from the plague attributed to Columba, 184 . 